\title{
Cell \& Cellular Life Sciences Journal
}

\section{Phytochemical Analysis and Antihelminthic Effects of Guierasenegalensis on Infected Rabbits}

\author{
Magashi LA ${ }^{1}$ and Ibrahim IAA ${ }^{2 *}$ \\ ${ }^{1}$ Chemistry Department, College of Education Gidan-Waya P.M.B.1024, Kafanchan, \\ Kaduna-Nigeria \\ ${ }^{2}$ Department of Science Lab Tec, School of Science and Technology, Abubakar Tatari \\ Ali Polytechnic Bauchi, Nigeria
}

Research Article

Volume 2 Issue 1

Received Date: June 27, 2017

Published Date: July 03, 2017

*Corresponding author: Ibrahim IAA, no.8 College of Agriculture Staff Quarters, Yelwa, Bauchi State, Nigeria, Tel: +2348069667795; Email: iliyasuibrahim@gmail.com

\section{Abstract}

The leaves of the common West African plant GuireaSenegalensis were analyzed for the presence of secondary metabolites. The qualitative analysis confirmed the presence of saponins, alkaloids, Flavounoids, tannins and steroids as active constituents of ethanolic extract which are similar to water extract with exception of steroids. Further investigation reveals the antihelminthic effect of GuireaSenegalensis by administering $200 \mathrm{mg} / \mathrm{kg}$ twice of leaves extract over a period of seven days using a rabbit's models; ethanol extracts revealed $50 \%$ effective and water extracts $28.57 \%$ effective.

Keywords: Phytochemical analysis; Guirea Senegalensis; Antihelminthic Rabbits; Helminths

\section{Introduction}

Helminths are worm-like parasites with complex reproductive system and life cycles involving intermediate host for the development of larval stages and a definitive host for the adult forms [1]. Research has established that helminthes infections are accompanied by reduced growth rate during childhood and by impaired nutrient utilization [1]. Hookworm infection affects iron status, often to the point where anaemia develops. Many species of helminthes have been reported as causing infections in humans and animal in many part of the world; nematode infection both soil-transmitted helminthiasis and lymphatic filariasis are having public health significance $[2,3]$.

Others include trematodes and cestodes [1]. More than 1.5 billion people, or $24 \%$ of the world's population, are infected with soil-transmitted helminth infections worldwide $[4,5]$. Infections are widely distributed in tropical and subtropical areas, with the greatest numbers occurring in sub-Saharan Africa, the Americas, China and East Asia [6]. Over 270 million preschool-age children and over 600 million school-age children live in areas where these parasites are intensively transmitted, and are in need of treatment and preventive interventions $[7,8]$.

Guiera Senegelensis commonly known as Sabara (in Hausa language) belongs to the Combretaceae family [9]. It is a tropical shrub used in traditional medicine for the treatment of stomach pain, dysenteric diarrhea, syphilis, beriberi, leprosy and impotence [10]. It is also used in veterinary medicine among the Tukolor people in diets designed to increase body weight, reproductive capacity and milk secretion in animals [9]. Powdered dried leaves of $G$. senegalensis associated with Melantherascandens are 


\section{Cell \& Cellular Life Sciences Journal}

administered by the nasal route to treat headaches and sinusitis. The leaves are also used as a poultice on tumors and against the guinea worm [11]. Several high quality investigations conducted on $G$. senegalensis have been found to possess pharmacological activities such as antimicrobial, antifungal, antioxidant and antiinflammatory effects on the central nervous system [11].

\section{Materials and Methods}

\section{Collection and Identification of Plant Material}

The leaves of G. Senegalensis were collected from Alkaleri Local Government Area of Bauchi State, Nigeria. The plant was authenticated at the Postgraduate Biology Laboratory of Abubakar Tafawa Balewa University, Bauchi.

\section{Preparation of Plant Material}

Ethanol extraction: $100 \mathrm{~g}$ of the powdered plant sample was weighed and place in the thimble of the soxhlet extractor. $200 \mathrm{ml}$ of ethanol was measured with a measuring cylinder and placed into the flask of the soxhlet extractor. Eight (8) anti-bumping clips were placed in the ethanol in order to prevent overheating and spill over. The soxhlet condenser was then connected and fixed tightly on the soxhlet chamber. It was extracted with ethanol for $6-8 \mathrm{hrs}$ at $50-60^{\circ} \mathrm{C}$. The crude extract obtained was concentrated in a rotary evaporator to obtain a greenish residue (EE). The weight and the percentage yield were calculated.

Water extraction: The powdered leaves $(100 \mathrm{~g})$ were extracted with $200 \mathrm{ml}$ distilled water using maceration method for 2days with occasional shaking. The extract was filtered using What Man No. 1 filter paper and the filtrate was freed from solvent with the aid of a water bath $\left(30-40^{\circ} \mathrm{C}\right)$ to obtain a gummy greenish product subsequently referred to as the water extract (WE). The weight and the percentage yield were calculated.

Phytochemical investigations: The extracts (EE and WE) were subjected to preliminary phytochemical screening for the presence of secondary metabolites such as flavonoids, alkaloids, saponins, tannins etc using standard procedures.

Preparation of animal sample: Three test rabbit were obtained in Bauchi metropolis and kept at school of agric., ATAP laboratory for intensive care. The animals were divided into three groups of one animal each. Group 1 served as the control while groups 2 and 3 served as the test groups. The test rabbits were infected with hookworm via feeding with contaminated feed (larva of hookworm mixed with their food and water).

Mode of administration of extract: The extracts $(200 \mathrm{mg} / \mathrm{kg})$ were administered to the test animals orally using a syringe while distilled water was administered to the control animal. Group 2 (R1) received ethanol extracts while group 3 (R2) was treated with water extracts.

\section{Determination of Antihelminthic Effect}

Stool microscopy: Stool microscopy was carried out weekly during the course of the research work the first was to determine the health status of the animals, then to confirm establishment of Ascaris infection and after treatment to assess the effectiveness of the plant extracts as antihelminthic. To carryout stool microscopy, 15 sterile specimen bottles were used in the morning to collect the freshly produced stool by the rabbits. Physiological saline, ( $0.85 \mathrm{~g}$ of sodium chloride into $100 \mathrm{ml}$ of distilled water) was used for emulsification, and later examined under the $\times 10$ objective of a light microscope. The number of eggs counted was then multiplied by 4 to give the number of eggs per gram of stool.

\section{Counting of Helminth Eggs}

Stoll's technique for counting helminth egg was carried out in the study; the counting of the hookworm egg was achieved by weighing $3 \mathrm{~g}$ of faeces in screw-cap container, $0.1 \mathrm{~mol} / \mathrm{L}$ solution of sodium hydroxide was added, using a rod, breaking up the faeces and mixing it in $\mathrm{NaOH}$. The container was cupped and shake hardly to complete the mixing, without delay using a wide bore Pasteur pipette about $0.15 \mathrm{ml}$ of the suspension was removed and transferred to the slide and was covered with cover slipped.

The entire preparation was examined systematically using x10 objective lens with the condense iris reduced to give good contrast, included in the count any egg's laying outside the edge of the cover glass because these are also contained in the $0.15 \mathrm{ml}$ sample. The number of eggs counted was multiplied by 100 to give the number of eggs per gram of faeces.

\section{Results}

The percentage yield of extraction for the methanol and aqueous extracts is presented in Tables 1 and 2 respectively. 


\section{Cell \& Cellular Life Sciences Journal}

Phytochemical profile of methanol and water extract of G. Senegalensis is shown in Table 3. Diagnosis of the test animals before and after contamination with the hookworm larvae is presented in Tables 4 and 5 respectively.
Antihelminthic effect of methanol and aqueous leaf extracts G. Senegalensis on rabbits after seven days of administration is shown in Table 6.

$$
\begin{aligned}
& \text { Weight of powered sample } \\
& \text { Weight of extract and container } \\
& \text { Weight of empty container } \\
& \text { Actual weight of extract }=\text { weight of container with extract }- \text { weight of container } \\
& =45.2 \mathrm{~g}-7.8 \mathrm{~g} \\
& \text { Percentage Yield }=\text { Final weight of extract } \times 100 \\
& \text { Initial weight of extract } \\
& =\quad \underline{37.4} \times 100 \\
& 100 \\
& =\quad 37.4 \%
\end{aligned}
$$

\begin{tabular}{|c|c|c|}
\hline \multirow{2}{*}{ Constituents } & \multirow{2}{*}{ Test } & Inferences \\
\hline & & EE WE \\
\hline Glycosides & Fehling's test & -- \\
\hline \multirow{2}{*}{ Alkaloids } & Mayer's test & ++ \\
\hline & Dragendorf's test & ++ \\
\hline \multirow{2}{*}{ Flavonoids } & Ferric chloride test & ++ \\
\hline & $\mathrm{NaOH}$ test & ++ \\
\hline Saponins & Frothing test & ++ \\
\hline \multirow{2}{*}{ Steroids } & Lieberman-Buchard & +- \\
\hline & Salkowski test & +- \\
\hline Tannins & Lead Sub-acetate & ++ \\
\hline
\end{tabular}

$100 \mathrm{~g}$

$45.2 \mathrm{~g}$

$7.8 \mathrm{~g}$

$37.4 \mathrm{~g}$

Table 1: Percentage yield of ethanol extraction.

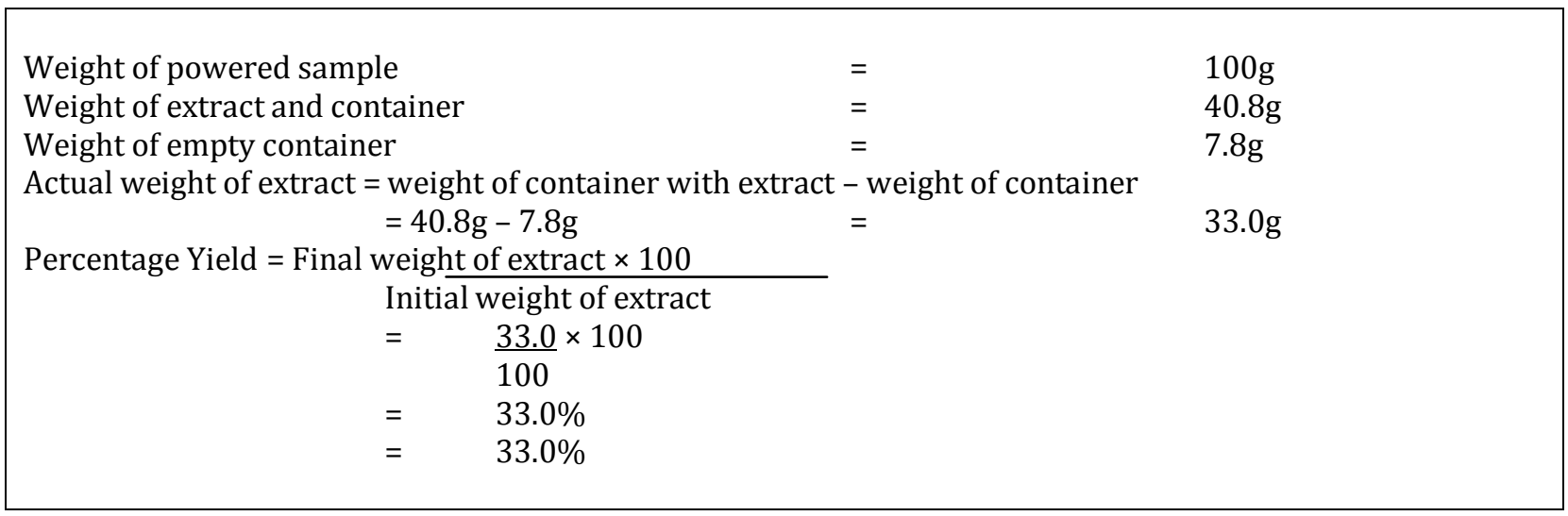

Table 2: Percentage yield of water extraction.

Key: $\quad+=$ Present - = Absent

Table 3: Phytochemical profile of ethanol and water extract of G. Senegalensis. 


\section{Cell \& Cellular Life Sciences Journal}

\begin{tabular}{|c|c|c|c|c|c|}
\hline Group & $\begin{array}{c}\text { Color of } \\
\text { specimen }\end{array}$ & Consistency & No. of eggs & $\begin{array}{c}\text { No. of eggs in } \\
\text { gram }\end{array}$ & Grade \\
\hline RC & Pale & Formed & - & - & - \\
\hline R1 & Pale & Formed & - & - & - \\
\hline R2 & Pale & Formed & - & - & - \\
\hline
\end{tabular}

Table 4: Screening of rabbit for Helminth at initial stage.

Key $\begin{aligned} & \mathrm{R} 2 \\
& \mathrm{R} C \\
& =\end{aligned}$
\begin{tabular}{|c|c|c|c|c|c|}
\hline Group & $\begin{array}{c}\text { Color of } \\
\text { Specimen }\end{array}$ & Consistency & $\begin{array}{c}\text { No. of eggs per } \\
\text { preparation }\end{array}$ & $\begin{array}{c}\text { No. of eggs } \\
\text { in gram }\end{array}$ & Grade \\
\hline $\mathrm{RC}$ & Pale & Semi-formed & 6 & 1200 & Few \\
\hline $\mathrm{R} 1$ & Yellow & Semi-formed & 4 & 800 & Few \\
\hline $\mathrm{R} 2$ & Pale & Semi-formed & 6 & 1400 & Few \\
\hline
\end{tabular}

Table 5: Result of rabbit's stool after contamination.

\begin{tabular}{|c|c|c|c|c|c|}
\hline Group & $\begin{array}{c}\text { Color of } \\
\text { Specimen }\end{array}$ & Consistency & $\begin{array}{c}\text { No. of eggs per } \\
\text { preparation }\end{array}$ & $\begin{array}{c}\text { No. of eggs } \\
\text { in gram }\end{array}$ & Grade \\
\hline RC & Yellow & Semi-formed & 6 & 1200 & Few \\
\hline R1 & Yellow & Semi-formed & 2 & 400 & Scanty \\
\hline R2 & Yellow & Semi-formed & 5 & 1000 & Few \\
\hline
\end{tabular}

Table 6: Result of rabbit's stool after administration of extract.

\section{Discussion}

The crude extracts of ethanol and water yields $37.4 \mathrm{~g} \%$ and $33.0 \%$ per $100 \mathrm{~g}$ of the test samples respectively[Table:1\&2]. Alkaloids, flavonoids, tannins, saponins and steroids were present in the ethanol extract while the water extract revealed the presence of all the constituents tested in ethanol including alkaloids, flavonoids, tannins and saponins with exception of steroids [Table:3]. These constituents have been reported to be associated with different pharmacological activities of plants ("Phytochemistry, Pharmacology and Ethnomedicinal Uses of Ficus Thonningii [12].

The screening of rabbits for helminth at initial stage [Table: 4] where all the rabbit are found with no infection. However, the investigation of rabbits before and after contaminating their food and water, and with administration of the extracts, results are found with different degree of infections; although they have the same grade of infections [Table: 5,6]. The results obtained shows the average result of investigation of rabbit's stool after administration of extract which shows its effect by reducing the number of eggs of helminth by $50 \%$ for ethanol and $28.57 \%$ for water.

\section{References}

1. Schabussova I (2014) Helminths and Helminthiasis, Ss

2. Alex L, Paul P (2001) Immune Responses in Hookworm Infections, J Clin Microbiol Rev 14(4): 689-703

3. Ayo OM, Osazuwa F, Imade P (2011) A significant association between intestinal helminth infection and anaemia burden in children in rural communities of Edo state, Nigeria. North American Journal of Medical Sciences 3(1): 30-34 


\section{Cell \& Cellular Life Sciences Journal}

4. Yapi RB, Chammartin F, Hürlimann E, Houngbedji CA, Prisca BN, et al. (2016) Bayesian risk profiling of soiltransmitted helminth infections and estimates of preventive chemotherapy for school-aged children in Côte d'Ivoire. Parasites \& vectors 9(1): 162.

5. Oswald WE, Stewart AE, Kramer MR, Endeshaw T, Zerihun M, et al. (2017) Association of community sanitation usage with soil-transmitted helminth infections among school-aged children in Amhara Region, Ethiopia. Parasites \& vectors 10(1): 91.

6. CDC - Parasites - About Parasites.

7. Mukherjee S, Mukherjee N, Gayen P, Roy P, Babu SP (2016) Metabolic Inhibitors as Antiparasitic Drugs, Pharmacological, Biochemical and Molecular Perspectives. Curr Drug Metab 17(10): 937-970.

8. Muiruri G, Mary GW (2016) Effects of Public Health Interventions on Intestinal Parasitic Infections among School-Going Children in Murang'a County, Kenya.
9. Kamal NSA, Elshafie AE, Nour A (2016) Antifungal and Phytochemical Analysis of Medicinal Compounds of Guiera senegalensis Leaves in Sudan. Plant Biochemistry \& Physiology Antitoxic 4(2): 2-5.

10. Salihu SO, Usman AA (2015) Antimicrobial and phytochemical study of the bioactive fractions of Guiera senegalensis from Alasan. Journal of Pharmacognosy and Phytochemistry 3(6): 106-111.

11. Mohammed SY (2013) Quantitative phytochemical and elemental analysis of Guiera Senegalensis leaf extract. Journal of Pharmacognosy and Phytotherapy 5(12): 204-207.

12. Rachael D, Kennedy HE, Davison M, Eliton C (2013) Phytochemistry, Pharmacology and Ethnomedicinal Uses of Ficus Thonningii (Blume Moraceae) A Review. Afr J Tradit Complement Altern Med 10(2): 203-212. 